\title{
THE EMERGENCE OF FASHION ELEMENTS IN FACEMASKS DURING THE EARLY STAGES OF COVID-19 PANDEMIC: EVIDENCE FROM SOCIAL MEDIA PART I: INVESTIGATION OF FACEMASK TRENDS AMONG INSTAGRAM FASHION INFLUENCERS
}

\author{
Elena Tomovska ${ }^{1 *}$ \\ 'Faculty of Technology and Metallurgy, University "Ss. Cyril and Methodius" \\ Skopje, Republic of North Macedonia \\ *e-mail: etomovska@tmf.ukim.edu.mk
}

Scientific paper

UDC: $316.35: 687: 391$

doi: 10.5937/tekstind2104030T

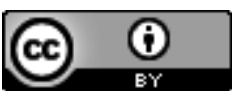

Abstract: The global Covid 19 pandemic introduced a new item in everyday dress-the facemask. During 2020, fashion elements crept in the design of this primarily functional item. This research aims to analyse fashion trends in facemasks in the early stages of the Covid 19 pandemic. Photos with facemasks on social media were used, as traditional fashion photography underrepresents facemask wearing. The research showed that fashion influencers on Instagram-the media of choice of the fashion industry, showed facemasks primarily as a PPE. The uncertainty on how long non-pharmaceutical solutions in the fight against Covid 19 will be in place raises the question if fashion should be ignored. When persuading people to wear facemasks could fashion be the carrot to the stick of legislation?

Keywords: Covid 19, facemasks, image sharing social media, fashion.

\section{POJAVA MODNIH ELEMENATA KOD MASKI ZA LICE TOKOM RANIH FAZA PANDEMIJE COVIDA-19: PODACI SA DRUŠTVENIH MREŽA I DEO: ISTRAŽIVANJE TRENDOVA MASKI KOD MODNIH INSTAGRAM INFLUENSERA}

Apstrakt: Globalna pandemija Covida-19 uvela je novi predmet u svakodnevnoj odeći-masku za lice. Tokom 2020. godine, modni elementi se pojavljuju u dizajnu ovog prvenstveno funkcionalnog predmeta. Ovo istraživanje ima za cilj analizu modnih trendova kod maski za lice u ranim fazama pandemije Covida-19. Korisćene su fotografije maski za lice na drustvenim mrežama, jer na tradicionalnalnim modnim fotografijama maske za lice se retko prikazuju. Istraživanje je pokazalo da su modni influenseri na Instagramu, društvenoj mreži koja je najuticajnija u modnoj industriji, koristili maske primarno u zaštinoj svrsi. Neizvesnost koliko dugo će se nefarmaceutska rešenja maski koristiti u borbi protiv Covida-19 nameće pitanje da li se moda treba ignorisati. Kod ubeđivanja ljudi da nose maske, da li bi moda bila šargarepa na štapu zakona?

Ključne reči: Covid-19, maska za lice, imiđ bazirane socijalne mreže, moda. 


\section{INTRODUCTION}

On March 11, 2020, the World Health Organization declared a global Covid 19 pandemic and brought with it a novel item in every day clothing - the facemask. Fashion is often oversimplified to a frivolous pastime, an attitude that ignores its role as a representative of the zeitgeist and deeper social, cultural, environmental and political fluctuations. With that in mind, the fashion aspects of facemasks worn during the early stages of COVID 19 become an interesting topic.

The creating process of functional clothing begins and ends with the user specific requirements [1]. Face masks belong to a subgroup of medical textiles termed personal protective equipment (PPE), in the form of surgical masks used for various medical procedures and filtering face-piece respirators (FFRs) recommended for use during aerosol-generating procedures on patients [2]. From the early stages of the pandemic, the use of facemasks, primarily for medical personnel and subsequently for the general public was advocated. As reported by the WTO [3], at the beginning of the pandemic around $50 \%$ of surgical masks were produced in China, Germany and the USA, while FFRs were mainly produced by Singapore. The rapid demand for facemasks combined with a disturbance of the global supply chain caused global shortages, leading to export bans on PPE imposed by a number of countries. Consequently, prices worldwide rocketed. All these factors promoted an "all hands to the deck" attitude in the production of homemade sewn textile masks for the general public. Textile masks were worn worldwide, even though they provide less [4]. In the process textiles scientist actively contributed by applying the existing body of knowledge, suggesting improved fitting solutions, application of nanotechnology [5,6], etc. In a rapidly developed science-policy interface changes in policy, including laws, regulations and government guidance were made [7]. In the era of social media, the inconsistencies in official recommendations caused a vociferous debate in the general public amongst the proponents and opponents of mask wearing through all possible outlets, yet masks became an inseparable part of the "new normal". The general pathway included firstly mandatory use of any type of masks in closed and crowded spaces, such as supermarkets or public transport; progressing in some countries to mandatory use of any type of masks in all public spaces; and lastly since January 2021 some countries started defining the types of masks to be used in order to provide protection.
Although the fashion industry reacted to the Covid 19 pandemic as early as February 2020 [8], it has been reluctant to include facemasks in the fashions it created. Face-masked audiences were in stark contrast with the mask-free faces on fashion runways, while Paris was the only fashion centre to acknowledge the change in dress [9]. Classical theories of fashion distinguish between a trickle-down, trickle-across and trickle-up diffusion [10], the last bearing most significance when facemask are considered.

Social media has become an indispensable part of common life. Fashion communication is of the upmost importance for the fashion industry [11], and image sharing social media are particularly well adopted for fashion communication [12]. Of the multitude of available social media Instagram has been widely adopted by the fashion industry. Designed as a platform for information sharing Instagram became a source for fashion inspiration [13] with fashion trends showcased by celebrities, as well as micro-influencers [14]. Post content such as "outfit of the day" allowed users to portray an often idealized self-image [15] and opened the media for various forms of overt and covert advertising. Although arriving later, both luxury [16] and high street fashion brands [17] embraced social media for marketing communication. Popular figures on Instagram are often embraced as fashion influencers [18] and mimic closely the trends in the fashion industry.

This research was undertaken to provide an analysis of fashion trends in facemasks in the early stages of the Covid 19 pandemic. As traditional fashion photography underrepresents facemask-wearing consumer driven image shearing social media was used for documenting facemasks in 2020. The first part of the research investigates the representation on facemasks among fashion influencers on Instagram.

\section{EXPERIMENTAL}

In order to quantify trends occurring in fashion photographic evidence is considered to provide more detailed and thorough insights than human memory does. Research used to qualify behaviors in the online community has been commonly termed as netnographic [18] and involves deeper understanding of the behaviour provided by interaction with the community Self-generated data in the form of posts, storylines, likes, shares, tweets, and live feeds on social media provide reasonable data that behaviours are changing [19]. The research steps on analysing fashion trends were adopted from Kim, Fiore \& Kim [20] and included awareness and observation, data 
searching and gathering, analysis, interpretation and synthesis.

Table 1: Presence of masks on

fashion influencers posts

\begin{tabular}{|c|c|c|c|c|}
\hline$\#$ & Region & Fashion Influencer & $\begin{array}{l}\text { Posts } \\
\text { total }\end{array}$ & $\begin{array}{c}\text { Posts } \\
\text { with } \\
\text { masks }\end{array}$ \\
\hline 1 & \multirow{25}{*}{ Global } & aislinnderbez & 1254 & 1 \\
\hline 2 & & anitta & 4429 & 1 \\
\hline 3 & & bernardokath & 1818 & 3 \\
\hline 4 & & chelseaoliviaa & 3038 & 1 \\
\hline 5 & & ddlovato & 282 & 2 \\
\hline 6 & & elrubiuswtf & 585 & 4 \\
\hline 7 & & emmaroberts & 1374 & 2 \\
\hline 8 & & gioewbank & 6256 & 2 \\
\hline 9 & & haileybieber & 1810 & 3 \\
\hline 10 & & hegdepooja & 1335 & 1 \\
\hline 11 & & kajalaggarwalofficial & 1810 & 1 \\
\hline 12 & & loren & 1413 & 2 \\
\hline 13 & & louisvuitton & 4702 & 8 \\
\hline 14 & & luisafernandaw & 4841 & 1 \\
\hline 15 & & paollaoliveriareal & 3745 & 1 \\
\hline 16 & & prillyatuconsina96 & 5599 & 1 \\
\hline 17 & & realbarbarapalvin & 1764 & 1 \\
\hline 18 & & sadiesink & 109 & 1 \\
\hline 19 & & shaymitchell & 5958 & 3 \\
\hline 20 & & simaria & 948 & 1 \\
\hline 21 & & skuukzky & 1323 & 3 \\
\hline 22 & & sofiavergara & 4345 & 3 \\
\hline 23 & & thehughejackman & 2429 & 7 \\
\hline 24 & & thenewclassic & 64 & 1 \\
\hline 25 & & uvrashirautela & 2666 & 1 \\
\hline 26 & \multirow{2}{*}{ France } & fidji_ruiz & 24 & 1 \\
\hline 27 & & iam_bilionare & 385 & 5 \\
\hline 28 & \multirow{5}{*}{ Australia } & mirandakerr & 2770 & 1 \\
\hline 29 & & rubyrose & 640 & 6 \\
\hline 30 & & leighannepinnock & 2470 & 3 \\
\hline 31 & & brooklynbeckham & 240 & 1 \\
\hline 32 & & amazingphil & 298 & 2 \\
\hline 33 & \multirow{2}{*}{ Russia } & sheidlina & 348 & 2 \\
\hline 34 & & nastyaivleeva & 910 & 2 \\
\hline 35 & \multirow{2}{*}{ Brazil } & julianapaes & 3223 & 1 \\
\hline 36 & & vivi & 1232 & 1 \\
\hline \multirow[t]{2}{*}{37} & India & shirleysetia & 948 & 2 \\
\hline & & Total & 77385 & 82 \\
\hline
\end{tabular}

Data from Instagram posts in the form of photographs as evidence of mask wearing in the period from February 2020 to November 2020 was collected from 1.11.2020 to 22.11.2020. The influencer marketing analytical platform Hypeauditor was used to identify fashion influencers. The list of the 50 top global fashion influencers was taken as a starting point. All influencers who had a post with a facemask in the period of March to November 2020 were included. As global influencers came from a distinct Anglo-American background, the search was broadened to include distinct linguistic and cultural areas by adding the top 10 fashion influencers from five different countries who did not occur on the global list, adding in total 50 profiles. The information was therefore limited to countries available on the Hypeauditor platform. As the information is pictorial, language was not a limiting factor. From Western Europe the profiles of the top influencers in France were examined, while from Eastern Europe Russia was selected. In a similar process Brazilian, Indian and Australian fashion influencers were included. In order to maximize the number of analysed photographs the choice of countries was biased towards those were mask were depicted. For example, of the European countries France, Italy and Germany, France was included as a preliminary search showed the largest number of photographs with masks. Still, on 63 profiles no photographs with masks were found. In total 37 profiles of fashion influencers were examined (Table 1), 25 global, five in Australia, two in France, Russia and Brazil and one in India. In total 82 photographs from Instagram were included in the research.

As the research was conducted during one month, it is limited only to photographs that are permanently present on Instagram - posts. The number of total posts in Table 1 presents the total number of posts at the profile since its inception, not the number of photographs posted in the investigated period. As Instagram was founded in 2012, assuming equal annual activity, the number of photographs posted in the period can be estimated to 9000 . However, it does not include temporary photographs - stories that might have occurred during the period. For instance, influencer profile no. 26 has only 24 permanent posts, as it mainly communicates via stories available for just 24 hours. The content presented on Instagram is highly dynamic and photos of masks may appear temporarily. None the less, the large number of profiles with no photos of masks at all expresses the reluctance of the fashion world to accept the masks as a fashion detail.

Visual analysis of each photograph was conducted in order to see the fashion trends emerging in facemasks. Analysis of hashtags sometimes were helpful in determining the context, but generally, the visual cues were sufficient. The criteria of function and decoration were used to determine if the facemask was used as a personal protection equipment or a decorative accessory. Where decoration occurred the style, colour and materials were analysed. Distinct patterns 
of trends in fashion masks occurred. When the information was gathered via Instagram the occurrence of the trend could also be precisely dated.

\section{RESULTS AND DISCUSSION}

Since facemasks were introduced the question of whether or not to wear a mask was posed, and it continues in the arena of social media. It can be seen throughout the fashion conscious community of Instagram, where fashion influencers mainly chose to be depicted without facemasks. An interesting visual commentary can be witnessed on profile no.34 (dated 22.10.2020, Figure 1) of a mask-less fashion influencer being filmed by a masked cameraperson. A clear parallel can be drawn to the fashion runways filled with mask free faces in comparison to the masked audiences. The dichotomy in mask wearing reality and maskless representation on fashion photography persists in social media, as well as in the fashion business.

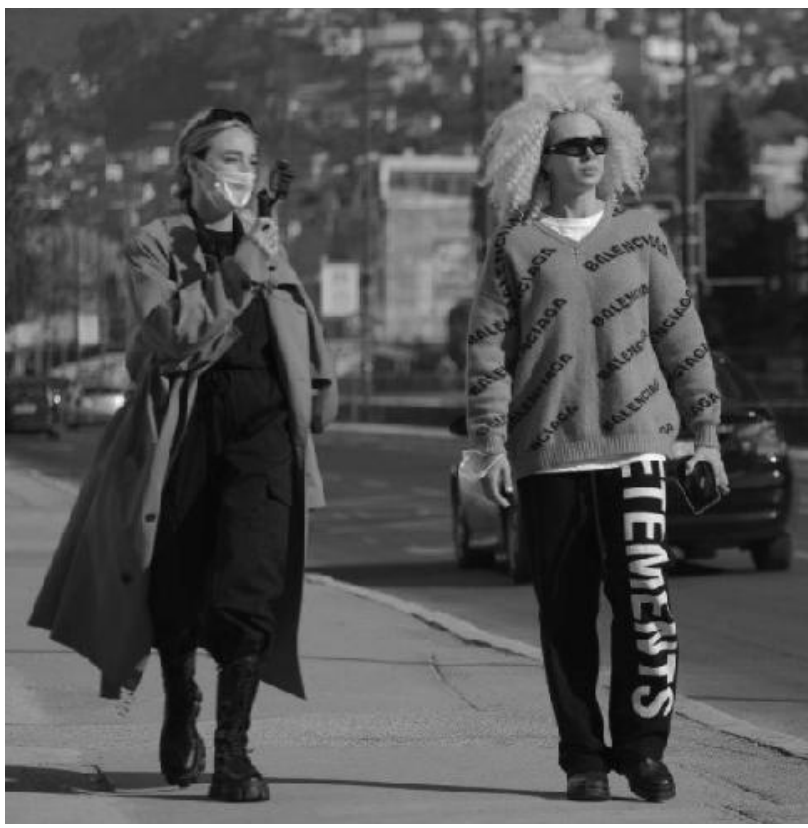

Figure 1: Reluctance of portrayal with face masks, Source: Nastya Ivleeva, 24.10.2020

Trends occurring on Instagram are dated and their popularity in certain months can be easily seen. Trends were divided in the categories of PPEs (frequency $f=32$ ), textile masks ( $f=14)$, with emerging subgroups of black masks $(f=15)$ and coordinated masks $(f=9)$, masks with a logo $(f=3)$, of which masks for the US elections are a subgroup $(f=7)$, scarves $(f=5)$, knitted masks $(f=2)$, masks as an art statement $(f=2)$. The total number of masks (89) is larger than the number of examined photographs as some had groups of people with different types of masks. The frequency per month of the most common trends is shown on Figure 2. Regarding the geographical emergence of trends of facemasks, the first photographs posted in March and April came from regional, rather than global influencers. They range from surgical masks in Australia (profile no. 28, 07.04.2020) and textile facemasks seen in Brazil (profile no.36, 21.03.20), to artistic representations of isolation such as a giant bubble covering the body of a person in a supermarket (profile no. 33, 26.03.2020).

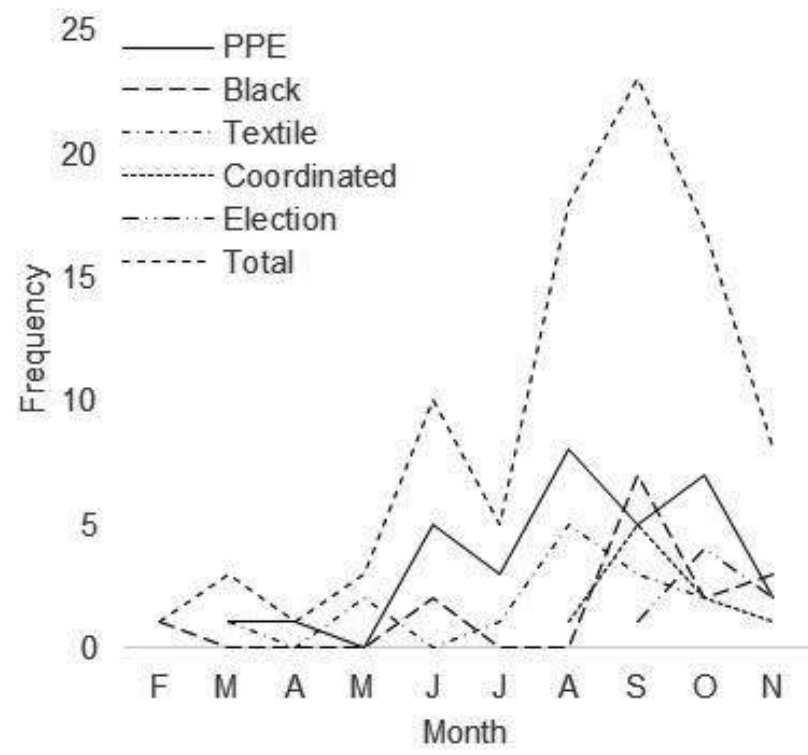

Figure 2: Facemask trends on Instagram from February to November 2020

Medical masks (PPE) are most prominently featured by Instagram influencers, thus emphasizing facemasks as a functional, rather than fashionable clothing accessory. The choice of medical facemasks on these profiles is in line with the global fashion industry dictum: to demonstrate individual responsibility and support in the global fight against the pandemic, but to clearly exclude facemasks as a fashion statement. On some profiles (e.g. no. 23 , figure 3,a), facemask wearing was part of an awareness raising campaign. The variation in medical masks ranges from surgical masks and FFRs, to improved fit FFRs, such as the Pure MSK commonly seen in Australia. None the less, the prolonged wearing of masks shyly introduces non-functional elements in the design, as can be seen by the colour variation in black FFRs since August 2020 (figure 3, b).

Simple textile masks, appear from March, with their popularity peaking in August. Masks with a simple print, cut with pleats, are worn in dissonance with the rest of the outfit. Although the print itself could be in a fashionable design (e.g. gingham), the general look conforms to the attitude of wearing masks as 
primarily functional clothing (figure $3, \mathrm{c}$ ). Variations in colour and print as elements of the design, set several trends in later months. Starting from September 2020, plain black masks became the most common choice of nonmedical textile masks among Instagram influencers.

Beginning with August 2020 coordinated masks made of an identical fabric as the outfit appear, introducing textile masks as a deliberately chosen fashion accessory (figure 3, d). Coordinated mask culminate in September with fashion show photographs from Louis Vuitton (profile no.13). Here the face covering is seen incorporated in the cut of the blouses, in the form of roll necks covering the face, as well as facemasks coordinated with the outfit. It is interesting that fashion houses in Paris, a fashion centre steeped in tradition, were the first to respond to the social cues and express them as a fashion statement. In comparison, the Instagram profile of Milan based Gucci - a source of best practice in Instagram marketing, in the examined period showed only photographs with plain FFRs, while their first post of a coordinated mask appeared as late as March 2021.

Masks with a logo worn to promote an event or a cause are also present. In particular, masks with the slogan "Vote" appeared in August, to express political attitudes during the US elections, reflecting the polarised stance towards facemask wearing during the campaign (Figure 3, e). Examples of support by the act of mere wearing a mask, accompanied by an explanatory hashtag are also seen (e.g. profile no.8, 15.11.2020). Besides posting their own photos, influencers also posted the masked democratic candi-

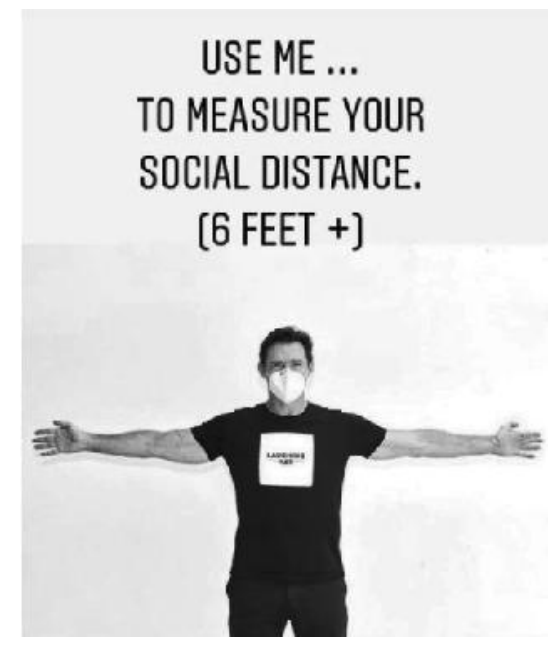

Source: thehughejackman, 07.07.2020

(a)

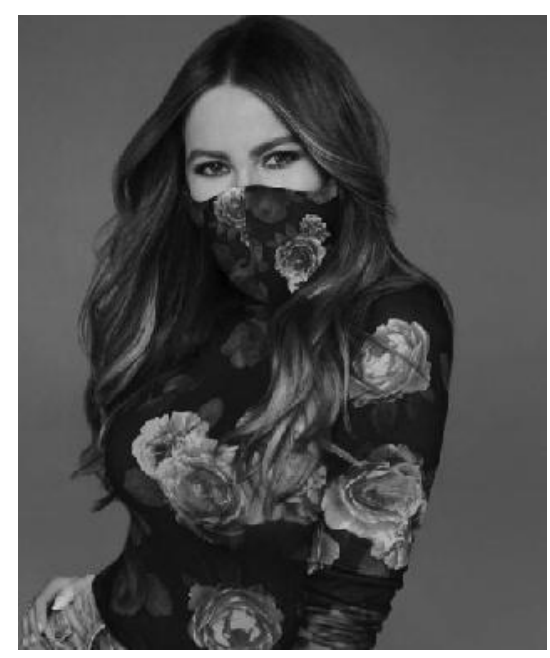

Source: sofiavergara, 06.10.2020

(d)

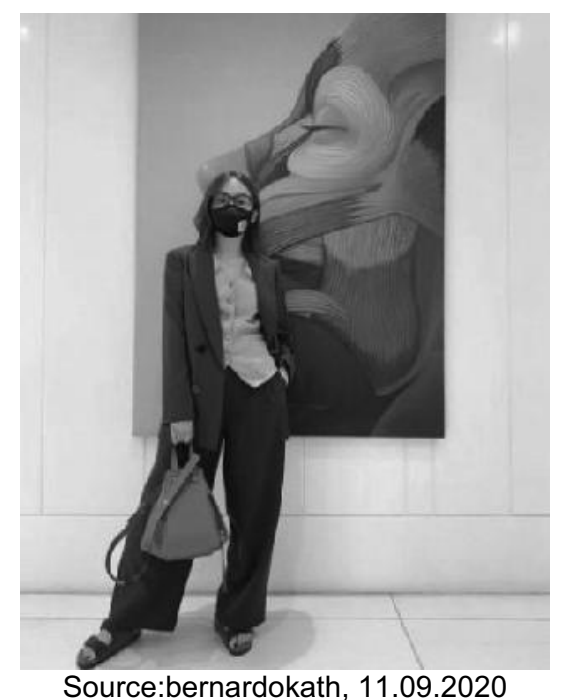

(b)

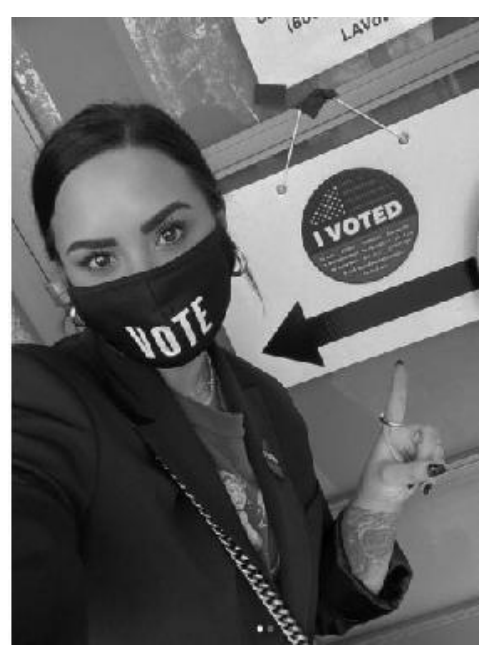

Source: ddlovato, 27.10.2020

(e)

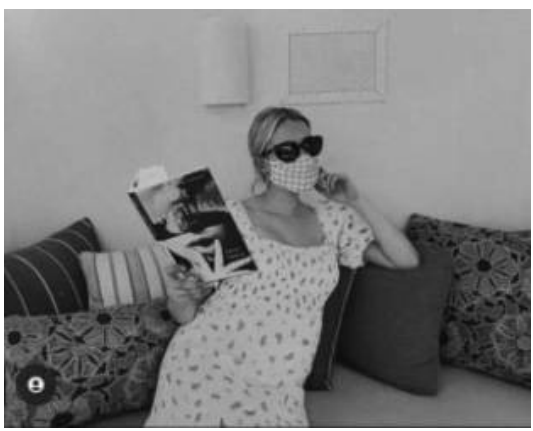

Source: emmaroberts, 01.10.2020

(c)

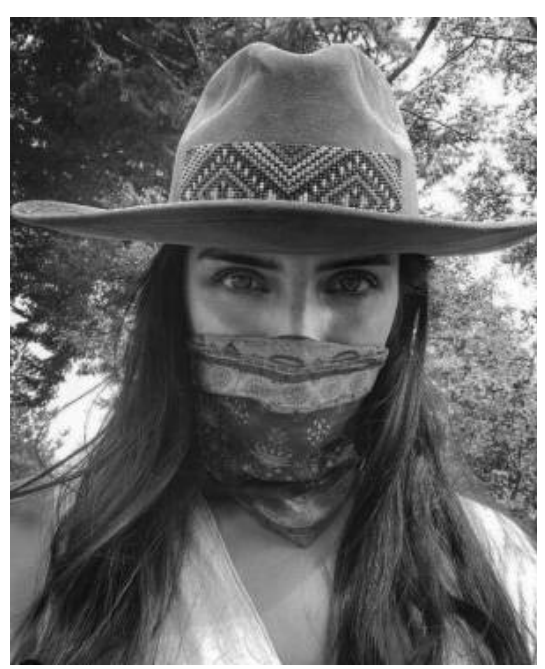

Source: aislinnderbez, 23.08.2020

(f)

Figure 3: Examples of facemask trends portrayed on Instagram 
dates during the campaign, indicating an intention to link facemask wearing with the values of that party.

Knitted masks are sparingly used, but are made in simple cuts with fine gauges. An interesting example to combine appearance with functionality could be seen on profile no. 27 as early as May 2020, featuring an inner surgical mask covered by a dark grey knitted mask. Given the difficulty in choosing a correct size of surgical masks this solution where the mask is closely fitted to the face by an elastic knitted fabric can be even considered increase functionality. The knitting industry also introduced facemask models in the past year, for example the one piece 3D Easy Mask, included in Stoll's knitting patterns for 2020. However, given the porosity of knits, to promote the mask Stoll used sustainability and "designed for recycling" labels, instead of fitness for medical purposes, for a selling point. As sustainability was the buzzword of the fashion industry in 2019, these masks can also be seen as a fashionable rather than a functional clothing accessory.

Finally, scarves present an alternative face covering to facemasks (Figure 3, f). Silk Hermes scarves started trending in the beginning of 2020, worn not only as a neckerchief, but also as a hair accessory or tied on bags. The organic transition from an available fashion accessory to face covering item emphasizes the fashion orientation of this trend. Hydrophilic silk fibres and fine fabrics contribute to a face covering with minimal personal protection function. Cotton bandanas, generally black, were used during the "Black lives matter" protests in June 2020. As bandanas are often worn during protests, expression of neo-liberal political attitudes via facemasks cannot be confirmed by these examples.

Region wise fashion influencers were least reluctant to post photos with facemask in Australia and France. The former had primarily examples of FFRs, indicative of a well-communicated policy of safe facemask wearing behaviour. In contrast, French influencers primarily chose to wear facemasks as a fashion statement.

\section{CONCLUSION}

During 2020, fashion elements crept in the design of a primarily functional clothing item - the facemask. This paper sought to demonstrate how fashion trends in facemasks were carried into their photographic representation on Instagram. The mandatory wearing of facemasks has left the fashion world struggling to find a unified response - a mirror, as ever, to the mixed feelings of society. The dichotomy of faces covered with masks in the physical environment and maskless faces presented in the virtual fashion community on Instagram is particularly noticeable. Still, there are noticeable trends arising in the facemasks worn by the Instagram fashion community.

By 2021, fashion has obviously found its way into facemasks. Considering the prolonged duration of the pandemic and the reluctance towards mask wearing fashion can be one of the possible solutions to increase social compliance.

\section{REFERENCES}

[1] Gupta, D. (2011). Design and engineering of functional clothing. Indian Journal of Fibre and Textile Research, 36 (4), 327-335.

[2] Morris, H. Murray, R. (2020). Medical textiles. Textile Progress, 70-77. https://doi.org/10.1080/00405167. 2020.1824468,

[3] World Trade Organization. (2020). Trade In Medical Goods In The Context Of Tackling Covid-19., (https://www.wto.org/english/news_e/news20_e/ rese_03apr20_e.pdf Accessed October 02.2020)

[4] Rubio-Romero, J.C., Pardo-Ferreira, M., Torrecilla-García, J.A., Calero-Castro, S. (2020). Disposable masks: Disinfection and sterilization for reuse, and non-certified manufacturing, in the face of shortages during the COVID-19 pandemic. Safety Science, 129. https://doi.org/10.1016/j.ssci.2020.104830

[5] Beesoon, S., Behary, N. Perwuelz, A. (2020). Universal masking during COVID-19 pandemic: Can textile engineering help public health? Narrative review of the evidence. Preventive Medicine. 139, 106236, https://doi.org/10.1016/j.ypmed.2020.106236.

[6] Park, S., Jayaraman, S. (2020). From containment to harm reduction from SARS-CoV-2: a fabric mask for enhanced effectiveness, comfort, and compliance. The Journal of The Textile Institute, https://doi.org/1 0.1080/00405000.2020.1805971.

[7] Martin, G.P., Hanna, E., McCartney, M. Dingwall, R. (2020). Science, society, and policy in the face of uncertainty: reflections on the debate around face coverings for the public during COVID-19. Critical Public Health, 30(5), 501-508

[8] Just-style. (2020). Timeline: coronavirus is impacting the global apparel industry. (https://www.juststyle.com/news/timeline-how-coronavirus-is-impacting-the-global-apparel-industry-free-to-read_ id138313.aspx, Accessed April 06 2020)

[9] Cartner-Morley, J. (2020). Chiffon face masks and chainmail balaclavas: an eerie end to a peculiar Par- 
is fashion week. The Guardian, (https://www.theguardian.com/fashion/2020/oct/06/chiffon-facemasks-and-chainmail-balaclavas-an-eerie-end-toa-peculiar-paris-fashion-week, Accessed January 08.)

[10] Davidovac-Nedeljkovic, M. (2016). Difuzija modnih trendova u modnom sistemu, Tekstilna Industrija, 64(1), 15-20.

[11] Završnik, B., Urošević, S. (2014). Značaj marketing komunikacionog miksa u tekstilnim i odevnim kompanijama, Tekstilna Industrija, 62(2), 33-38.

[12] Tomovska, E. (2020). The Role of Instagram Influencers as a Source of Fashion Information, Tekstilna Industrija, Vol 68(4), 58-65.

[13] Aragoncillo, L. Orus, C. (2018). Impulse buying behaviour: an online-offline comparative and the impact of social media, Spanish Journal of Marketing - ESIC, 22(1), 42-62.

[14] Martensen A., Schack B. S., Zahid L. A. (2018). How citizen influencers persuade their followers, Journal of Fashion Marketing and Management: An International Journal, https://doi.org/10.1108/JFMM-092017-0095

[15] Abidin C. (2016). Visibility labour: Engaging with Influencers' fashion brands and \#OOTD advertorial campaigns on Instagram. Media International Australia, 161(1), 86-100.

[16] Kusumasondjaja, S. (2019). Exploring the role of visual aesthetics and presentation modality in luxury fashion brand communication on Instagram.
Journal of Fashion Marketing and Management: An International Journal, 24(1),15-31.

[17] Bonilla, M., Arriaga, J.L., Andreu, D. (2019). The interaction of Instagram followers in the fast fashion sector: The case of Hennes and Mauritz (H\&M). Journal of Global Fashion Marketing, 10 (4), 342-357.

[18] Hudders, L., De Jans, S., De Veirman, M. (2020). The commercialization of social media stars: a literature review and conceptual framework on the strategic use of social media influencers. International Journal of Advertising, https://doi.org/10.1080/0265048 7.2020.1836925.

[19] Weichelt, B., Nambisan, P., Burke, R., Bendixsen, C. (2020). Finding the Edges of Problems: Social Media as an Exploratory Research Tool. Journal of Agromedicine, 25(4), 423-426.

[20] Kim, E., Fiore, A.M. Kim, H. (2011). Fashion Trends analysis and Forecasting. Oxford:Berg.

Primljeno/Received on: 7.11.2021.

Revidirano/ Revised on: 17.11.2021.

Prihvaćeno/Accepted on: 21.11.2021.

(c) 2021 Authors. Published by Union of Textile Engineers and Technicians of Serbia. This article is an open access article distributed under the terms and conditions of the Creative Commons Attribution 4.0 International license (CC BY) (https://creativecommons. org/licenses/by/4.0/) 